\title{
Antioxidant effectivity to decrease coronal microleakage of composite resin restoration after intra-coronal bleaching
}

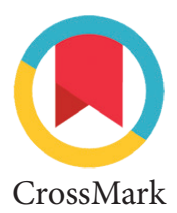

\author{
Yusri,, Aries C. Trilaksana, Chiristine A. Rovani
}

\section{Abstract}

Objective: This study aimed to compare the ability of the three antioxidant ingredients and a minimal application to decrease microleakage of composite resin restoration after intracoronal bleaching. Material and Methods: Fifty maxillary firstincisor that met the inclusion criteria were prepared endodontic treatment. They are divided into 10 groups: control group (no antioxidant), sodium ascorbate 10\%, catalase $10 \%$ and sodium ascorbate $10 \%$ with Tween $800.2 \%$ and an application period of 1 hour, 24 hours and 48 hours. Applied hydrogen peroxide 35\% for 5 days. Samples were restored with composite resin and coated with nail polish, placed China ink for 24 hours.

Results: Coronal microleakage was assessed using a stereomicroscope, which showed presented a significant different $(p<0.05)$ in 48 hours. Conclusion: Sodium ascorbate 10\% with tween $800.2 \%$ had a significant effect in decreasing coronal microleakage in 48 hours.
Department of Conservative Dentistry, Faculty of Dentistry, Hasanuddin University, Makassar, Indonesia

\footnotetext{
* Correspondence to:
} ucidentist96@gmail.com

Received: 18 August 2016 Revised: 15 November 2016 Accepted: 22 November 2016 Available Online: 18 December 2016

Keywords: Antioxidan, Bleaching, Coronal microleakage, Composite restoration

Cite this Article:Yusri, Trilaksana AC, Rovani CA. 2016. Antioxidant effectivity to decrease coronal microleakage of composite resin restoration after intra-coronal bleaching. Journal of Dentomaxillofacial Science 1(3): 158-162. D0I: 10.15562/jdmfs.v1i3.309

\section{Introduction}

Intracoronal bleaching material that is often used is hydrogen peroxide, carbamide peroxide and sodium perborate. However, hydrogen peroxide bleaching agents have the highest concentrations that can produce more radical peroxide, so the bleaching process become faster. ${ }^{1,5}$ Generally, after the procedure intracoronal bleaching followed by composite resin restorations to avoid recontamination bacteria. ${ }^{6}$ In some studies have suggested restoration procedures to be delayed for 14 to 21 days to remove residual peroxide overall. ${ }^{7-11}$ Oxygen and free radicals build the main mechanism of action on the tooth bleaching done by penetrating through the porosity of the prism email to dentin leaving residual peroxide component. Peroxide is disturbing resin polymerization resulting in the increase of microleakage coronal and decrease the sealing ability of composite resin restorations. ${ }^{2,6,11}$

A number of methods is able to eliminate the side effects of bleaching, among others: removing the surface layer of email, applications alcohol before restoration, using the adhesive containing solvent organic. ${ }^{1,7,8}$ However, that methods cause discomfort, then improve the adhesion of composite resins on non-vital tooth used antioxidant ingredients. Applications of antioxidant ingredients aims to reduce the waiting time between bleaching and restoration procedures to the disappearance of reactive oxygen species on the surface of the tooth. ${ }^{7,8}$
Some antioxidant ingredients, either type enzyme or non enzyme has been known to include: superoxidase dismutase (SOD), sodium ascorbate, ascorbic acid (vitamin $\mathrm{C}$ ), vitamin $\mathrm{E}$, glutathione peroxidase and catalase. But only few were found to be effective. ${ }^{8,10}$ Sodium ascorbate soluble in water and can remove free radicals in the body's biological system. ${ }^{6,7}$ With high $\mathrm{pH}$, this material is best applied on the tooth structure. ${ }^{6}$ Tween $800.2 \%$ is a surfactant nonionic when added to facilitate antioxidant ingredients antioxidant ingredients penetrating into the dentin. ${ }^{8,10}$

Based on the findings above, this research will compare the ability of sodium ascorbate $10 \%$, sodium ascorbate 10\% combined tween $800.2 \%$, catalase $10 \%$ and the time required by the application of the three materials to the decline of coronal microleakage of composite resin restorations after bleaching intrakoronal use hydrogen peroxide $35 \%$.

Some antioxidant ingredients, either type enzyme or non enzyme has been known to include: superoxidase dismutase (SOD), sodium ascorbate, ascorbic acid (vitamin C), vitamin E, glutathione peroxidase and catalase. But only few were found to be effective. ${ }^{8,10}$ Sodium ascorbate soluble in water and can remove free radicals in the body's biological system. ${ }^{6,7}$ With high $\mathrm{pH}$, this material is bestapplied on the tooth structure. ${ }^{6}$ Tween $800.2 \%$ is a surfactant nonionic antioxidants when added 
to the material to facilitate antioxidant ingredients penetrating into the dentin. ${ }^{8,10}$

Based on the findings above, this research will compare the ability of sodium ascobate $10 \%$, sodium ascorbate $10 \%$ combined with tween 80 $0.2 \%$, catalase $10 \%$ and the time required by the application of the three materials to the decline of coronal microleakage of composite resin restorations after bleaching intracoronal use 35\% hydrogen peroxide.

\section{Material and Methods}

This study carried out a study design post test only control group, the design was conducted in April-May 2016 the manufacture of the catalase enzyme from liver extract and chicken heart in The Laboratory of the Organic Chemistry Department of Chemistry Faculty of Mathematic and Science Hasanuddin University and scoring coronal microleakage in Laboratory Research Center of Hasanuddin University. The sample used was the central incisors as many as 50 samples (there are no caries, cracks, hypoplastic area and teeth do not get endodontic treatment) is immersed in a solution of $0.5 \%$ chloramine $\mathrm{T}$ was then placed in a saline solution with a temperature of $4^{\circ} \mathrm{C}$ for 2 weeks. The teeth were prepared with a crown down pressureless technique using ProTaper rotary files (dentsply maillefer) size F1 to F5. Then obturated using gutta percha (dentsply maillefer) and cement-based resin sealer (AH Plus), gutta percha issued up to $2 \mathrm{~mm}$ from the cemento enamel junction and closed base glass ionomer cement. Intracoronal bleaching performed using 35\% hydrogen peroxide (opalescent-endo-Ultradent, USA) for 5 days and during this bleaching procedure samples were stored in $\mathrm{NaCl}(0.9 \%)$ at a temperature of $37^{\circ} \mathrm{C}$ and replaced twice a day. Once the procedure is completed intracoronal bleaching, the pulp chamber is irrigated with 2 $\mathrm{ml}$ of distilled water. The samples were divided into 10 groups, including a control group without the application of antioxidants. Antioxidant ingredients, sodium ascorbate 10\% (Sigma Aldrich, USA), sodium ascorbate $10 \%$ combined Tween $800.2 \%$, catalase $10 \%$ placed into the pulp chamber near temporary fillings stored in tubes containing saline-filled glass. Teeth in groups 2-10 was incubated in a temperature of $37^{\circ} \mathrm{C}$ for 1 hour, 24 hours and 48 hours and then removed from the tube and sprayed with water and air. The samples were then restored composite resin (Z350, color A2, 3M ESPE, USA) according to the manufacturer's instructions. The entire sample is dried and applied three coats of nail polish on all surfaces except the $1 \mathrm{~mm}$ from the edge of the

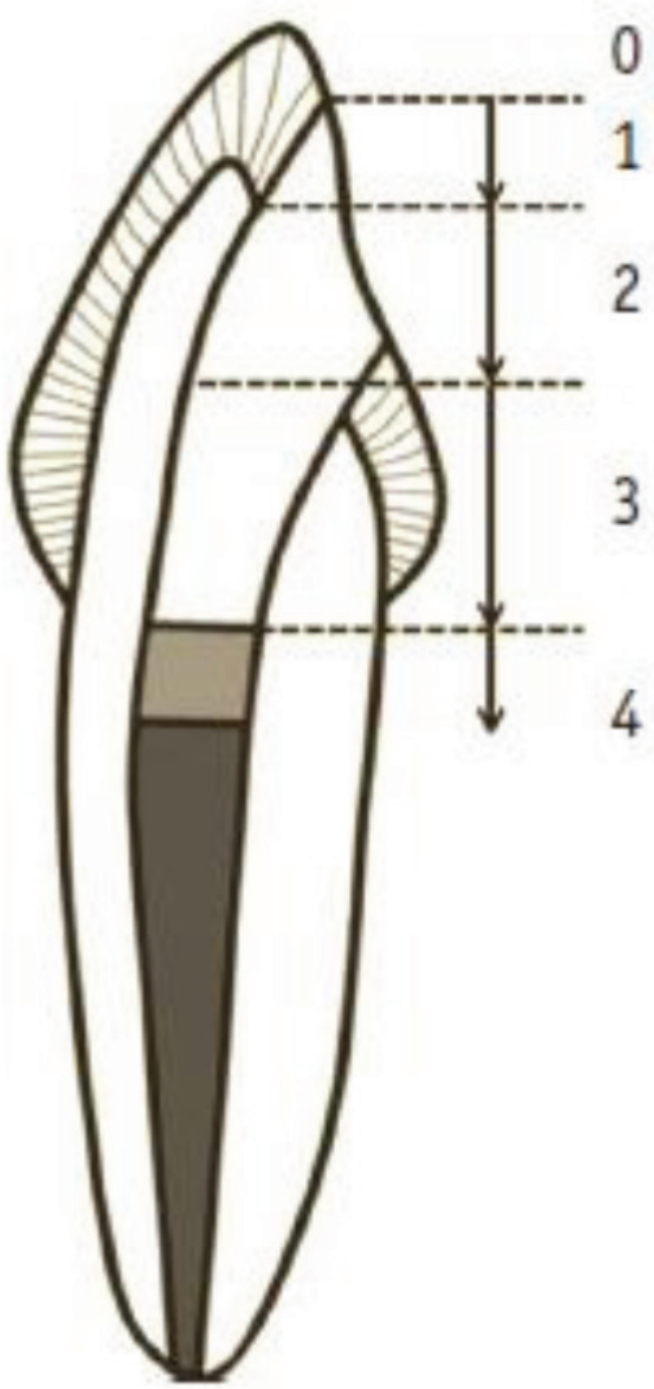

Figure 1 Criteria for evaluation of coronal microleakage. Score 0: no penetration of color; 1: penetration of color only on enamel; 2: penetration of color to a half into the cavity; 3 : color penetration of more than a score of 2 without involving gutta percha; 4: color penetration involving gutta-percha

restoration. Samples were immersed in India ink for 24 hours at a temperature of $37^{\circ} \mathrm{C}$ and then rinsed with running water and removed using acetone nail polish. Dried for $1 \times 24$ hours. The next stage is the teeth are cut longitudinally from buccal to lingual aspect through the central part of the restoration of coronal and root canal filling using low-speed and carborondum disk.

Chinese ink penetration depth is evaluated from the root tip to the coronal with a stereo microscope. By category score of 0-4.6 figure 1

Data were tested with Friedmann test, KruskalWallis and Newman-Keuls multiple comparison $(\rho<0.05)$. 
Table 1 Scores of penetration (microleakage) between the intervention groups at the time of observation 1 hour, 24 hours, and 48 hours

\begin{tabular}{|c|c|c|c|c|c|c|}
\hline \multirow{2}{*}{$\begin{array}{l}\text { Antioxidant } \\
\text { Group }\end{array}$} & 1 hour & \multirow[b]{2}{*}{ p-value } & \multirow{2}{*}{$\begin{array}{c}24 \text { hours } \\
\text { Mean } \pm \text { SD }\end{array}$} & \multirow[b]{2}{*}{ p-value } & \multirow{2}{*}{$\begin{array}{c}48 \text { hours } \\
\text { Mean } \pm \text { SD }\end{array}$} & \multirow[b]{2}{*}{ p-value } \\
\hline & Mean \pm SD & & & & & \\
\hline $\begin{array}{l}\text { Sodium Ascorbate } \\
10 \%\end{array}$ & $3.40 \pm 0.54$ & \multirow[b]{3}{*}{0.663} & $2.40 \pm 0.54$ & \multirow[b]{3}{*}{$0.018^{\star}$} & $1.60 \pm 0.54$ & \multirow{4}{*}{$0.003^{*}$} \\
\hline Catalase $10 \%$ & $3.40 \pm 0.54$ & & $3.00 \pm 0.00$ & & $2.40 \pm 0.54$ & \\
\hline $\begin{array}{l}\text { Sodium Ascorbate } \\
10 \%+\text { Tween } 80 \\
0.2 \%\end{array}$ & $3.20 \pm 0.44$ & & $2.60 \pm 0.54$ & & $1.40 \pm 0.54$ & \\
\hline Control & $3.60 \pm 0.54$ & & $3.60 \pm 0.54$ & & $3.60 \pm 0.54$ & \\
\hline
\end{tabular}

Note: Normality test, Shapiro-Wilk test: $\mathrm{p}<0.05$; distribution data abnormal

${ }^{\star}$ Kruskal-Wallis test: $\mathrm{p}<0.05$; significant

Table 2 The result of continuing difference test among antioxidant of sodium ascorbate $10 \%$, catalase $10 \%$, combination of sodium ascorbate and tween $800.2 \%$, and control group during 24 and 48 hours of observation

\begin{tabular}{|c|c|c|c|c|c|}
\hline Observational time & Antioxidant (i) & Comparative (j) & $\begin{array}{c}\text { Mean } \\
\text { Difference } \\
(\mathbf{i}-\mathbf{j})\end{array}$ & $\begin{array}{c}95 \% \mathrm{Cl} \\
\text { (min-max) }\end{array}$ & p-value \\
\hline \multirow[t]{6}{*}{24 hours } & Sodium Ascorbate 10\% & Catalase $10 \%$ & -0.600 & $-1.24-0.04$ & 0.063 \\
\hline & & $\begin{array}{l}\text { Sodium Ascorbate } \\
10 \%+\text { Tween } 800.2 \%\end{array}$ & -0.200 & $-0.84-0.44$ & 0.514 \\
\hline & & control & -1.200 & $-1.84--0.56$ & $0.001^{\star}$ \\
\hline & Catalase $10 \%$ & $\begin{array}{l}\text { Sodium Ascorbate } \\
10 \%+\text { Tween } 800.2 \%\end{array}$ & 0.400 & $-0.24-1.04$ & 0.201 \\
\hline & & Control & -0.600 & $-1.24-0.04$ & 0.063 \\
\hline & $\begin{array}{l}\text { Natrium Ascorbate } \\
10 \%+\text { Tween } 800.2 \%\end{array}$ & Control & -1.000 & $-1.64--0.36$ & $0.004^{*}$ \\
\hline \multirow[t]{6}{*}{48 hours } & Sodium Ascorbate 10\% & Catalase $10 \%$ & -0.800 & $-1.53--0.07$ & $0.035^{\star}$ \\
\hline & & $\begin{array}{l}\text { Sodium Ascorbate } \\
10 \%+\text { Tween } 800.2 \%\end{array}$ & 0.200 & $-0.53-0.93$ & 0.572 \\
\hline & & Control & -2.000 & $-2.73--1.27$ & $0.000^{*}$ \\
\hline & Catalase $10 \%$ & $\begin{array}{l}\text { Sodium Ascorbate } \\
10 \%+\text { Tween } 800.2 \%\end{array}$ & 1.000 & $0.27-1.73$ & $0.011^{*}$ \\
\hline & & Control & -1.200 & $-1.93--0.47$ & $0.003^{*}$ \\
\hline & $\begin{array}{l}\text { Sodium Ascorbate } 10 \%+ \\
\text { Tween } 800.2 \%\end{array}$ & Control & -2.200 & $-2.93--1.47$ & $0.000 *$ \\
\hline
\end{tabular}

\section{Results}

The study result indicates that in one-hour observation, mean score of sodium ascorbate $10 \%$ and catalase $10 \%$ groups perform the highest score compare to the control group, they are 3.4 each. Meanwhile, Natrium $10 \%$ and tween $80 \quad 0.2 \%$ combination group is the lowest score. Furthermore, there is no significant penetration score difference among those antioxidant groups. In the 48 hours observation, found the significant difference of penetration score among sodium ascorbate $10 \%$, catalase $10 \%$, sodium ascorbate and tween 80 0.2\% combination and control group table 1.
In the 24 hours observations, significant difference only found in the differentiation betweensodium ascorbic $10 \%$ and control. There is no significant difference between sodium ascorbate $10 \%+$ tween $800.2 \%$ and control. There is no significant difference between sodium ascorbate $10 \%$, catalase $10 \%$, sodium ascorbate and tween 80 $0.2 \%$ combinations as well as between catalase and combination of sodium ascorbate $10 \%$ and tween $800.2 \%$. After 48 hours, found significant difference between sodium ascorbate $10 \%$ and catalase $10 \%$; between sodium ascorbate $10 \%$ and control; 
between catalase $10 \%$ and control; between catalase $10 \%$ and combination of sodium ascorbate $10 \%+$ tween 80 0.2\%; and between control and combination of sodium ascorbate $10 \%$ + tween 80 0.2\% table 2.

\section{Discussion}

Coronal microleakage is a factor of endodontic failure and a main factor which determine teeth restoration age. ${ }^{12,13}$ Study conducted by Deoliveira et al. ${ }^{14}$ stated that hydrogen peroxide residue change the tubular permeability and inter-prismatic area, facilitated hydrogen peroxide residue in inhibiting polymerization and cause coronal microleakage occurrence. $^{14}$

The result indicates that all study groups conduct coronal microleakage. Coronal microleakage signed by China ink penetration. Color penetration occurred as the result of dimensional changing which include the composite of polymerization shrinkage resin, thermal expansion coefficient differentiation between teeth and resin composite restoration as well as hygroscopic absorption of composite resin restoration. This change caused the formation of gape between teeth structure and composite restoration called coronal microleakage. ${ }^{15}$ Appeared irregular hybrid layer in teeth email which conduct bleaching than un-bleaching teeth email and this may lead to coronal microleakage improvement. ${ }^{16}$

The high score of coronal microleakage in control group caused by peroxide residue gave a bad effect to the composite resin sticky in the teeth structure. Hydrogen peroxide application may lead to protein denaturation in dentin and email's organic component, change the organic and anorganic ratio with the organic component improvement. The changing caused by bleaching agent lead to decline of calcium and phosphate in email which changing the email crystal morphology and organic matrix as well as teeth dentin..$^{1,2,17}$

Previous study proved that peroxide ion exchange occurred with radical hydroxyl in apatit plexus and result in apatit peroxide, cause the structural changing in apatit plexus. Antioxidant application is a substance that neutralize free radicals by donor its electron, which stop the reaction of electron loss. The three antioxidant substances in this study can remove peroxide residue from teeth structure then increasing the adhesion between composite resin restoration and structural teeth in bleached teeth. ${ }^{7-10}$

Microleakage coronal score in sodium ascorbate combined with Tween $800.2 \%$ for 48 hours is the lowest. This may because the addition of tween 80
$0.2 \%$ which is a non-ionic surfactant. Surfactant help antioxidant agent to penetrate on dentin thus dentinalistubulus efficacy and email are better. ${ }^{9}$ The previous study conducted by Moosavi et al. ${ }^{9}$ advise that surface tension and contact edge of bleached teeth cavity can be reduced and increasing cohesive ability after applied sodium ascorbate $10 \%$ combined with Tween $800.2 \% .^{18}$

The study result in 4.2 indicates that there is significant decline of coronal microleakage in all antioxidant agents at the 24th and 48th hour. It is different from the study conducted by Lai using sodium ascorbat, an antioxidant agent, but with different bleaching agent that is carbamid peroxide $10 \%$ stated that sodium ascorbate $10 \%$ application before restoration will not cause premature termination and in his opinion it needs application time, about 10 minutes..$^{10,19}$

Electrochemistry and topography study performed that sodium ascorbate application may remove peroxide ion of plexus apatit. After sodium ascorbate contacted with free oxygen of hydrogen peroxide then sodium ascorbate will be oxidize then formed crystal ascorbate on the email surface.

The difference of coronal microleage in all three groups of antioxidant in the continuing-difference test by Mann Whitney in 48 hours observation time, indicates a significant score $(\mathrm{p}<0.05)$. It can be seen at table 4.2. It means that the combination between sodium ascorbate $10 \%$ and tween $800.2 \%$ is very pleasure in minimalize the occurrence of coronal microleakage in 48 hour after restoration.

Study conducted by Khoroushi et al. ${ }^{20}$ suggested that there is certain time to remove peroxide residue step by step from the bleached teeth surface before restoration procedure is conducted. ${ }^{20}$ It also proofs that sodium ascorbate 10\% application after 3 days in the pulpa room may increase the sealing ability of composite resin restoration. ${ }^{6,20}$ Possible differentiation occurrence caused by the antioxidant substance time, which in this study, the maximum application time is 48 hour and score 0 is not found but 1. It means that in 48 hours there is a significant microleakage score decreasing but incompletely loss. Therefore, restoration can be conducted.

\section{Conclusion}

Sodium ascorbate $10 \%$ and tween $800.2 \%$ decline the composite resin restoration of coronal microleakage for 48 hours application. Further study must be conducted to observe the effectivity of sodium ascorbate $10 \%$, catalase $10 \%$ and the combination of Sodium ascorbate $10 \%$ and tween $800.2 \%$ by increasing their concentration. 


\section{Conflict of Interest}

The authors report no conflict of interest.

\section{References}

1. Plotino G, Nicola M, Grande, et al. Nonvital tooth bleaching: a review of the literature and clinical procedure. JOE 2008;34: 394-407.

2. Pasricha S. Comparative evaluation of microleakage of tooth coloured restorative materials after exposure to $33 \%$ hydrogen peroxide- an in-vitro study. Int J Contem Dent 2011;2: 28-34.

3. Valera MC, Camargo CHR, Carvalho CAT, et al. Jappl Oral Sci 2009;17: 254-261.

4. Lim MY, Lum SOY, Poh RSC, et al. An in vitro comparison of the bleaching efficacy of 35\% Carbamide peroxide with established intracoronal bleaching agents. IEJ 2004;37: 483-488.

5. Goldberg M, Grootveld M, Lynch E. Undesirebeld and effects of tooth-whitening products: a review. Clin Oral Invest 2010;14: 1-10.

6. Park JY, Kwon TY, Kim YK. Effective application duration of sodium ascorbate antioxidant in reducing microlekage of bonded composite restoration in intracoronally-bleahed teeth. RDE 2013: 43-47.

7. Braz R, Patricio CE, Riberio AIAM, et al. Influence of antioxidants on stress of bonding agents in recently whitened teeth. Acta Odontal Latinoam 2011;24: 252-257.

8. Da-Silva JMG, Botta AC, Barcellos DC, et al. Effect of antioxidant agents on bond strength of composite to bleached enamel with $38 \%$ hydrogen peroxide. Materials Res 2011;14: 235-238.

9. Moosavi H, Moghaddes MJ, Ghodussi J, et al. Effects of two antioxidants on microleakage of resin based composite restorations after non vital bleaching. The J Contemporary Dent Practise 2010;11: 1-8.
10. Han Y, Mo S, Jiang L, et al. Effects antioxidants on the microlekage of composite resin restoration after external tooth bleaching. Europ J Dent 2014;8: 147-153.

11. Perchyonok VT, Grobler SR. Tooth bleaching: mechanism, biological aspects and antioxidants. Int J Dent Oral Health 2015;1: 1-7.

12. Wang W, Wang YJ, Wang DQ. Dual effect of Tween 80 on protein stability. Int J Pharmaceutics 2008;347: 31-38.

13. Carrilho E, Abrantes M, Paula A, et al. Microleakage study of a restorative material via radioisotope methods. Rev Port EstomatolMed Dent CIR Maxilofac 2014;55: 129-134.

14. De-oliveira MT, De-Andrade MAC, Michels M. Oxygen release, microleakage and shear bond strength of composite restorations after home dental bleaching. Rev Odonta Cienc 2011;26: 45-49.

15. ADA council. Tooth whitening/Bleaching: treatment consideration for dentist and their patients. ADA 2009: 1-5.

16. Jacob AS, Kumar NMD. Effect of pre and post operative bleaching on microleakage of amalgam and composite restoration using $10 \%$ Carbamide peroxide- An invitro study. PubMed 2007;10: 33-37.

17. Marion JJC, Manhaes FC, Bajo H, et al. Effect of different concentration of sodium hypochlorite during endodontic treatment. Literature review. Dental Press Endod 2012;2: 32-37.

18. Umar I, Kamalak H. Bleaching discolored devital teeth with using of new agents. IOSR-JDMS 2014;13: 79-82.

19. Lai SC, Tay FR, Cheung GS, et al. Revesal of compromised bonding in bleached enamel. J Dent Rest 2002;81:447-481.

20. Khoroushi M, Feiz A, Ebadi M. Influence of intermediary filling material on microleakage of intracoronally bleached and restored teeth. Dent Res J 2009;6: 17-22.

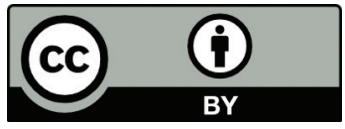

This work is licensed under a Creative Commons Attribution 